\title{
Effects of CPPU Applications on Southern Highbush Blueberries
}

\author{
Jeffrey G. Williamson ${ }^{1}$ \\ Horticultural Sciences Department, University of Florida, P.O. Box 110690, \\ Gainesville, FL 32611-0690
}

\author{
D. Scott NeSmith \\ Department of Horticulture, University of Georgia, Griffin Campus, Griffin, \\ GA 30223
}

Additional index words. Vaccinium corymbosum, growth regulator, fruit set

\begin{abstract}
Greenhouse and field experiments were conducted to determine the effects of the growth regulator $\mathrm{N}$-(2-chloro-4-pyridyl)- $\mathrm{N}^{\prime}$-phenylurea (CPPU) on fruit set, berry size, and yield of southern highbush blueberry (Vaccinium corymbosum hybrids). The experiments were conducted over a period of several years in Georgia and Florida. CPPU sprays were capable of increasing fruit set and berry weight of southern highbush blueberry, although the responses to CPPU treatment were variable and appeared to be influenced by factors such as rate, spray timing, and cultivar. In Florida, high natural fruit set may have prevented increased fruit set from CPPU. A slight delay in berry maturity was noted in several experiments. Spray burn occurred on several occasions and may be related to factors such as cultivar, rate, spray volume, and use of surfactant.
\end{abstract}

Poor fruit set and suboptimum berry size are potential yield- and profit-limiting factors for southern highbush (Vaccinium corymbosum hybrids) blueberry production. Factors that commonly affect fruit set include pollinator population during bloom, weatherrelated factors that influence pollinator activity and pollen transfer during bloom, and freezing temperatures during or after bloom, which damage ovules and ovaries thereby inhibiting seed and fruit development. Much research over the past decade has focused on use of $\mathrm{GA}_{3}$ to overcome fruit set problems in blueberries grown in the lower southeastern United States (NeSmith, 2005). Although $\mathrm{GA}_{3}$ has increased fruit set of blueberry, there are problems regarding late ripening and reduced fruit size associated with its use.

The cytokinin compound N-(2-chloro-4pyridyl)- $\mathrm{N}^{\prime}$-phenylurea (CPPU) has shown some positive results in increasing fruit size and fruit set in a number of fruit crops, including table grapes (Vitis sp.), kiwifruit (Actinidia chinensis Planch and A. deliciosa), apples [Malus $\times$ domestica (Borkh.)], table olives (Olea eropaea L.), and Japanese persimmon (Diospyros khaki Thunb.) (Antognozzi et al., 1993a, 1993b; Greene, 1989, 1993; Looney, 1993; Reynolds et al., 1992; Sugiyama and Yamaki, 1995). Recently, preliminary research has shown that CPPU may also be beneficial in rabbiteye blueberry production (NeSmith, 2002; NeSmith and Adair, 2004); however, there has been no research

Received for publication 9 Mar. 2007. Accepted for publication 24 June 2007.

We thank Valent BioSciences Corp., Libertyville, IL, for their financial support of this research.

${ }^{1}$ To whom reprint requests should be addressed; e-mail jgrw@ufl.edu. reported on CPPU effects on southern highbush blueberries. The objective of this research was to evaluate the response of several southern highbush cultivars to applications of CPPU under greenhouse and field conditions.

\section{Materials and Methods}

This research was conducted under both field and greenhouse conditions over several years. The greenhouse experiments were conducted at the University of Georgia Research Station in Griffin, GA. Field experiments were conducted at the University of Georgia Blueberry Research Farm in Alapaha, GA, on a commercial blueberry farm in Appling County, GA, and on two commercial blueberry farms in Alachua County, FL.

\section{Greenhouse experiments}

Experiments were conducted in 2001 and 2003. One-year-old southern highbush blueberry plants were grown in pine bark in 12-L (2001) or 4-L (2003) containers. Plants were grown outdoors through the winter until after bloom and the application of CPPU treatments. Flower development was monitored, and dates of $50 \%$ open blooms were determined. CPPU treatments were applied based on the number of days after $50 \%$ bloom referred to here as days after flowering (DAF). All CPPU applications consisted of spraying whole plants to the point of drip using a backpack sprayer. All sprays used the nonionic surfactant X-77 at $0.25 \%(\mathrm{v} / \mathrm{v})$. After flowering was complete, plants were moved to a greenhouse for the remainder of the experiment. Percent fruit set and average individual berry weight were determined for each treatment. Fruit set was determined by counting the number of flowers per plant and the total number of fruit. Berry weight was determined by weighing each fruit individually as it was harvested.

In 2001, the following treatments were applied to 'Magnolia' and 'Reveille': 1) a nontreated control; 2) a single application of $5 \mathrm{mg} \cdot \mathrm{L}^{-1}$ of CPPU applied at 14 DAF; 3) a single application of $10 \mathrm{mg} \cdot \mathrm{L}^{-1}$ of CPPU applied $14 \mathrm{DAF}$; and 4) two applications of $5 \mathrm{mg} \cdot \mathrm{L}^{-1}$ of CPPU at 10 and 20 DAF. In 2003, five treatments were applied to 'Star', 'Legacy', and 'Palmetto'. They were: 1) a nontreated control; 2) $5 \mathrm{mg} \cdot \mathrm{L}^{-1}$ of CPPU applied $7 \mathrm{DAF}$; 3) $10 \mathrm{mg} \cdot \mathrm{L}^{-1}$ of CPPU applied 7 DAF; 4) $5 \mathrm{mg} \cdot \mathrm{L}^{-1}$ of CPPU applied $14 \mathrm{DAF}$; and 5) $10 \mathrm{mg} \cdot \mathrm{L}^{-1}$ of CPPU applied $14 \mathrm{DAF}$. The cultivars bloomed at different times, so CPPU applications were made relative to a particular cultivar's bloom date. 'Star' bloomed on Mar. 12, 'Legacy' bloomed on Mar. 17, and 'Palmetto' bloomed on Mar. 26.

\section{Georgia field experiments}

2001 experiment. Mature plants (more than 6 years old) of four southern highbush cultivars were used for this experiment. 'Georgiagem' and 'Palmetto' plants were located at the UGA research farm, and 'Reveille' and 'Bladen' were located on a commercial blueberry farm in Appling County, GA. Two treatments were applied to single plant plots of each of the four cultivars. The treatments were: 1 ) a nontreated control; and 2) $10 \mathrm{mg} \cdot \mathrm{L}^{-1}$ of CPPU applied 10 to 14 DAF. CPPU was applied using a backpack sprayer and whole plants were sprayed to the point of drip. The nonionic surfactant X-77 was included in all CPPU treatments at $0.25 \%(\mathrm{v} / \mathrm{v})$. There were six replications (single plants) of each treatment on each cultivar. All plants were exposed to bees and other pollinators. Fruit set of all plants was determined by tagging two shoots per plant and counting the number of flowers per shoot and later counting the number of fruit. At the beginning of commercial harvest time, 50-berry samples were collected from plants to determine berry weight. Additionally, a determination of the percent ripe fruit on a specified date was made for the treatments for each cultivar.

2005 experiment. This research was conducted under field conditions during 2005 at a grower site in Ware County, GA. Mature southern highbush blueberry plants were used for this experiment. Three cultivars were used: 'Millennia', 'O'Neal', and 'Bluecrisp'. Flower development of plants was monitored and dates of $50 \%$ open blooms were determined. CPPU treatments were applied based on the number of days after flowering. There were four treatments for each of the cultivars. These were: 1) a nontreated control, only pollination; 2) $10 \mathrm{mg} \cdot \mathrm{L}^{-1}$ of CPPU applied 10 to $14 \mathrm{DAF}$ without surfactant; 3$) 10 \mathrm{mg} \cdot \mathrm{L}^{-1}$ of CPPU applied 10 to 14 DAF with $0.05 \% \mathrm{v} / \mathrm{v}$ surfactant (Silwet L-77, Helena Chemical Co., Collierville, TN); and 4) $15 \mathrm{mg} \cdot \mathrm{L}^{-1}$ of CPPU applied 10 to 14 DAF without surfactant. All CPPU applications consisted of spraying whole plants to the point of drip using a 
backpack sprayer. There were four replications (four plants each replication) of each treatment and cultivar.

Fruit set of all plants was determined by tagging two shoots per plant and counting the number of flowers per shoot and later counting the number of fruit. At the beginning of commercial harvest time, 50-berry samples were collected from plants to determine berry weight. Additionally, a determination of the percent ripe fruit on a specified date was made for the treatments for each cultivar.

\section{Florida field experiments}

2001 experiment. Three field experiments (one experiment per cultivar) were conducted using mature, field-grown 'Santa Fe', 'Star', and 'Sharpblue' southern highbush blueberry plants located on a commercial blueberry farm in Alachua County, FL. Each experiment (cultivar) consisted of the following treatments: 1) $10 \mathrm{mg} \cdot \mathrm{L}^{-1}$ of CPPU applied $14 \mathrm{~d}$ after full bloom; 2) $5 \mathrm{mg} \cdot \mathrm{L}^{-1}$ of CPPU applied $10 \mathrm{~d}$ after full bloom and $5 \mathrm{mg} \cdot \mathrm{L}^{-1}$ applied $10 \mathrm{~d}$ later; 3) $5 \mathrm{mg} \cdot \mathrm{L}^{-1}$ of CPPU applied $14 \mathrm{~d}$ after full bloom; 4) $10 \mathrm{mg} \cdot \mathrm{L}^{-1}$ of CPPU applied $10 \mathrm{~d}$ after full bloom and $10 \mathrm{mg} \cdot \mathrm{L}^{-1}$ applied $10 \mathrm{~d}$ later; and 5) a control consisting of water and surfactant applied at $14 \mathrm{~d}$ after full bloom. Sprays were applied to runoff with a backpack sprayer $(\approx 1200 \mathrm{~L} / \mathrm{ha})$. Triton B 1956 was used as a surfactant $(0.05 \% \mathrm{v} / \mathrm{v})$ in all treatments. Full bloom was determined by assessing flower bud development twice weekly.

Randomized complete block designs with five replications were used for each experiment. Individual plots consisted of two data plants with a one-plant buffer on either side. Four representative shoots were randomly selected on each data plant. Flower number and development were measured on each shoot. Ripe berries were harvested at 3- to 4-d intervals from the selected shoots and from whole plants for one data plant per plot. For individual shoots, berry number and average fruit fresh weight were measured and berry set per flower bud was determined. Average berry weight was determined for each treatment by subsampling 10 fruit from each plant at each harvest date. Analysis of variance was used to determine the effects of rate and time of spray on response variables. Duncan's multiple range test was used to separate treatment means.

2002 experiment. Two field experiments (one experiment per cultivar) were conducted using mature, field-grown 'Millennia' and 'Star' southern highbush blueberry plants located on a commercial blueberry farm in Alachua County, FL. Each experiment consisted of the following treatments: 1) $10 \mathrm{mg} \cdot \mathrm{L}^{-1}$ of CPPU applied at full bloom; 2) $10 \mathrm{mg} \cdot \mathrm{L}^{-1}$ of CPPU applied $7 \mathrm{~d}$ after full bloom (DAFB); 3) $10 \mathrm{mg} \cdot \mathrm{L}^{-1}$ of CPPU applied 14 ('Star') or 20 ('Millennia') DAFB; 4) $5 \mathrm{mg} \cdot \mathrm{L}^{-1}$ of CPPU applied at full bloom plus $5 \mathrm{mg} \cdot \mathrm{L}^{-1}$ applied $7 \mathrm{~d}$ later; 5) $5 \mathrm{mg} \cdot \mathrm{L}^{-1}$ of CPPU applied 7 DAFB plus $5 \mathrm{mg} \cdot \mathrm{L}^{-1}$ applied 14 ('Star') or 20 ('Millennia') DAFB; and 6) a nontreated control. Sprays were applied with a backpack sprayer to provide thorough coverage, which ranged from 650 to $1200 \mathrm{~L} \cdot \mathrm{ha}^{-1}$ depending on plant size. Full bloom was determined by assessing flower bud development twice weekly. Full bloom was considered to be when $72 \%$ ('Millennia') or $40 \%$ ('Star') of the florets were at or past the fully expanded and open stage of development.

Randomized complete block designs with seven replications were used for both experiments. Individual plots consisted of one data plant with buffer plants on either side. Eight representative shoots were randomly selected on each data plant. Flower number and development were measured on each shoot. All ripe berries were harvested at 3- to 4-d intervals from the selected shoots and from whole plants. Individual shoots were used to determine fruit set, which was expressed as fruit number per flower bud. Average berry weight was determined for each treatment by subsampling 10 fruit from each treatment at each harvest date. Analysis of variance was used to determine the effects of rate and time of spray on response variables. Duncan's multiple range test was used to separate treatment means.

\section{Results and Discussion}

\section{Greenhouse experiments}

2001 experiment. Fruit set of 'Magnolia' was increased substantially by all applications of CPPU as compared with the control treatment (Table 1). Fruit set of 'Reveille' was increased only for the $5-\mathrm{mg} \cdot \mathrm{L}^{-1}$ single CPPU application. Berry size of 'Reveille' and 'Magnolia' was increased by $15 \%$ to $25 \%$ with a single application of $5 \mathrm{mg} \cdot \mathrm{L}^{-1}$ of CPPU when compared with the control berries. An additional increase in berry size was achieved for the $10-\mathrm{mg} \cdot \mathrm{L}^{-1} \mathrm{CPPU}$ application for 'Magnolia'. When $5 \mathrm{mg} \cdot \mathrm{L}^{-1} \mathrm{CPPU}$ was applied in two split applications, berry size was not improved for either cultivar.

Some phytotoxicity occurred in the form of leaf burn or necrosis with CPPU applications on southern highbush. The burning occurred primarily on newly emerging leaf buds. The degree of damage depended on stage of plant development and CPPU rate. The 5-mg. $\mathrm{L}^{-1}$ single application caused less damage than the $10-\mathrm{mg} \cdot \mathrm{L}^{-1}$ single applica- tion; however, the treatment that consisted of two applications of $5 \mathrm{mg} / \mathrm{L}$ of CPPU $10 \mathrm{~d}$ apart caused the greatest leaf burn. A plausible reason for this is that the first application caused some leaf burn, which stimulated additional leaf budbreaks. The second application $10 \mathrm{~d}$ later caused additional damage on these newly emerging leaves. Southern highbush blueberry plants receiving the split application were reduced in vigor for the remainder of the experiment because of the loss of leaves.

2003 experiment. The effect of CPPU on fruit set of southern highbush blueberries depended on CPPU concentration, application timing, and cultivar (Table 2). The most positive response in fruit set was observed for the cultivar 'Legacy', when $10 \mathrm{mg} \cdot \mathrm{L}^{-1}$ of CPPU was applied 14 DAF. However, this same treatment on 'Palmetto' considerably lessened fruit set as compared with the control. 'Star' showed a trend for a slight increase in fruit set for most of the CPPU treatments.

Berry fresh weight was increased for all cultivars when CPPU was applied at 14 DAF (Table 2). Conversely, only 'Legacy' responded to the 7 DAF treatments. The treatment showing the most consistent response across cultivars was $5 \mathrm{mg} \cdot \mathrm{L}^{-1}$ of CPPU applied 14 DAF. This treatment increased berry weight from $20 \%$ to $40 \%$ depending on cultivar. Generally, 'Legacy' was most responsive and 'Star' least responsive to increased berry weight from CPPU treatments. Some damage to young, emerging leaf buds similar to that observed in 2001 was observed for some of these CPPU treatments in 2003.

\section{Georgia field experiments}

2001 experiment. Effects of a single application of $10 \mathrm{mg} \cdot \mathrm{L}^{-1}$ of CPPU on four field-grown southern highbush cultivars are depicted in Table 3. Two of the four cultivars ('Georgiagem' and 'Palmetto') had increased fruit set in response to CPPU, one cultivar ('Bladen') had decreased fruit set, and one cultivar ('Reveille') showed no effect of CPPU on fruit set. CPPU increased berry size of 'Reveille' and 'Bladen' by $20 \%$ compared with control berries, but there was no influence of CPPU on berry size for

Table 1. Fruit set and berry weight of two southern highbush blueberry cultivars in response to CPPU treatments under greenhouse conditions.

\begin{tabular}{lcr}
\hline & \multicolumn{2}{c}{ Cultivar } \\
\cline { 2 - 3 } CPPU treatment & Magnolia & Reveille \\
\hline & & Fruit set (\%) \\
Control $^{\mathrm{z}}$ & $44.7 \pm 7.2^{\mathrm{y}}$ & $73.5 \pm 10.0$ \\
$5 \mathrm{mg} \cdot \mathrm{L}^{-1}$ at $14 \mathrm{DAF}$ & $96.1 \pm 3.2$ \\
$10 \mathrm{mg} \cdot \mathrm{L}^{-1}$ at $14 \mathrm{DAF}$ & $69.7 \pm 10.7$ & $77.4 \pm 9.1$ \\
$5 \mathrm{mg} \cdot \mathrm{L}^{-1}$ at $10 \mathrm{DAF}+5 \mathrm{mg} \cdot \mathrm{L}^{-1}$ at $20 \mathrm{DAF}$ & $73.6 \pm 10.3$ & $72.7 \pm 5.1$ \\
& $69.2 \pm 8.4$ & Individual berry weight $(\mathrm{g})$ \\
$\mathrm{Control}$ & $1.51 \pm 0.09$ & $1.75 \pm 0.11$ \\
$5 \mathrm{mg} \cdot \mathrm{L}^{-1}$ at $14 \mathrm{DAF}$ & $1.89 \pm 0.07$ & $2.01 \pm 0.07$ \\
$10 \mathrm{mg} \cdot \mathrm{L}^{-1}$ at $14 \mathrm{DAF}$ & $2.00 \pm 0.16$ & $1.80 \pm 0.06$ \\
$5 \mathrm{mg} \cdot \mathrm{L}^{-1}$ at $10 \mathrm{DAF}+5 \mathrm{mg} \cdot \mathrm{L}^{-1}$ at $10 \mathrm{DAF}$ & $1.57 \pm 0.07$ & $1.60 \pm 0.06$ \\
\hline
\end{tabular}

${ }^{\mathrm{z} C o n t r o l s ~ w e r e ~ n o t ~ t r e a t e d . ~}$

${ }^{\mathrm{y}}$ Values are means $\pm \mathrm{SE}$ with $\mathrm{n}=6$.

${ }^{\mathrm{x}} \mathrm{DAF}=$ days after flowering. 
'Georgiagem' or 'Palmetto'. CPPU tended to delay ripening for all cultivars, although, in many cases, the difference of percent ripe was small. No great degree of phytotoxicity was observed in response to CPPU applications.

2005 experiment. CPPU treatments increased fruit set of 'Bluecrisp' and 'Millennia' but not 'O'Neal' (Table 4). Fruit set of the nontreated controls was much higher for 'O'Neal' than for the other cultivars and this may explain the lack of increase in fruit set from CPPU treatments. The presence or absence of a surfactant did not seem to consistently affect fruit set. CPPU at $10 \mathrm{mg} \cdot \mathrm{L}^{-1}$ did not increase berry weight when no surfactant was included in the spray. However, with the addition of surfactant, berry weight was increased for 'Millennia' and 'O'Neal' but not 'Bluecrisp'. The greatest increase in berry weight was observed with 'Millennia'. CPPU applied at $15 \mathrm{mg} \cdot \mathrm{L}^{-1}$ without surfactant did increase berry weight of 'Bluecrisp', although the magnitude of the increase was not great.

Considerable injury to young, emerging leaf buds was observed for CPPU treatments on 'O'Neal' and 'Bluecrisp', especially in the presence of a surfactant. In fact, severe damage was noted on 'Bluecrisp' as early as $5 \mathrm{~d}$ after treatment. The injury was more pronounced by $15 \mathrm{~d}$ after treatment. In addition to the leaf injury, berry injury was also observed on 'O'Neal' that received CPPU applications with a surfactant. No leaf or fruit injury was detected on 'Millennia' for any of the CPPU treatments.

There was a slight delay in fruit ripening with CPPU for some of the cultivars (data not shown). The control plants nearly always had berries that began ripening sooner than CPPU treatments. Similar observations of some delay have been seen in our tests in other years.

\section{Florida field experiments}

Fruit set was not increased by CPPU treatments in either year (data not shown). In 2001, fruit set was decreased for 'Sharpblue' and 'Santa Fe' by the split application of $10 \mathrm{mg} \cdot \mathrm{L}^{-1}$ CPPU. Reduced fruit set appeared to be related to spray burn injury to developing leaves or flowers, which was severe for this treatment. Fruit set was unaffected for 'Star', which showed the least amount of spray burn of the three cultivars tested in 2001. In 2002, fruit set was unaffected by any CPPU treatment. This may have been because natural fruit set was high and at, or close to, the carrying capacity of the plants and no spray injury was observed during 2002. Effects on fruit yield from CPPU varied with cultivar and year. In 2001, most CPPU treatments increased yield of 'Star' but not 'Santa Fe' or 'Sharpblue' (Table 5). In fact, yield of 'Sharpblue' was decreased by the $10-\mathrm{mg} \cdot \mathrm{L}^{-1}$ split application treatment. Yield appeared to be heavily influenced by spray burn in 2001. 'Sharpblue', which showed the most spray injury of the three cultivars tested, also had reduced yields for the split application of $10 \mathrm{mg} \cdot \mathrm{L}^{-1}$ CPPU and a trend toward reduced yields for
Table 2. Fruit set and berry weight of three southern highbush blueberry cultivars in response to CPPU treatments under greenhouse conditions.

\begin{tabular}{lccc}
\hline & \multicolumn{3}{c}{ Cultivar } \\
\cline { 2 - 4 } CPPU treatment & Star & Legacy & Palmetto \\
\hline Control $^{2}$ & $74.5 \pm 5.4^{y}$ & Fruit set $(\%)$ & \\
$5 \mathrm{mg} \cdot \mathrm{L}^{-1}$ at $7 \mathrm{DAF}^{\mathrm{x}}$ & $77.4 \pm 5.1$ & $58.5 \pm 6.1$ & $64.2 \pm 6.5$ \\
$10 \mathrm{mg} \cdot \mathrm{L}^{-1}$ at $7 \mathrm{DAF}$ & $88.0 \pm 2.8$ & $65.3 \pm 5.3$ & $52.1 \pm 8.3$ \\
$5 \mathrm{mg} \cdot \mathrm{L}^{-1}$ at $14 \mathrm{DAF}$ & $80.5 \pm 4.5$ & $68.5 \pm 5.8$ & $54.2 \pm 10.1$ \\
$10 \mathrm{mg} \cdot \mathrm{L}^{-1}$ at $14 \mathrm{DAF}$ & $80.8 \pm 5.6$ & $69.0 \pm 5.0$ & $23.4 \pm 7.4$ \\
& & $80.9 \pm 3.5$ & \\
Control & $1.40 \pm 0.13$ & Individual berry weight $(\mathrm{g})$ & \\
$5 \mathrm{mg} \cdot \mathrm{L}^{-1}$ at $7 \mathrm{DAF}$ & $1.60 \pm 0.23$ & $1.50 \pm 0.04$ & $1.18 \pm 0.09$ \\
$10 \mathrm{mg} \cdot \mathrm{L}^{-1}$ at $7 \mathrm{DAF}$ & $1.52 \pm 0.11$ & $2.15 \pm 0.12$ & $1.31 \pm 0.14$ \\
$5 \mathrm{mg} \cdot \mathrm{L}^{-1}$ at $14 \mathrm{DAF}$ & $1.71 \pm 0.16$ & $2.16 \pm 0.06$ & $1.22 \pm 0.05$ \\
$10 \mathrm{mg} \cdot \mathrm{L}^{-1}$ at $14 \mathrm{DAF}$ & $1.55 \pm 0.12$ & $1.97 \pm 0.21$ & $1.59 \pm 0.09$ \\
\hline
\end{tabular}

${ }^{\mathrm{z}}$ Controls were not treated.

yValues are means $\pm \mathrm{SE}$.

${ }^{\mathrm{x}} \mathrm{DAF}=$ days after flowering.

Table 3. Effects of CPPU on fruit set, berry size, and degree of ripening of field-grown southern highbush blueberries in Georgia during 2001.

\begin{tabular}{|c|c|c|c|c|}
\hline \multirow[b]{2}{*}{ CPPU treatment } & \multicolumn{4}{|c|}{ Cultivar } \\
\hline & Reveille & Bladen & Georgiagem & Palmetto \\
\hline & \multicolumn{4}{|c|}{ Fruit set (\%) } \\
\hline Control $^{z}$ & $56.9 \pm 6.0^{\mathrm{y}}$ & $50.3 \pm 5.3$ & $37.8 \pm 4.2$ & $49.4 \pm 7.3$ \\
\hline \multirow{2}{*}{$10 \mathrm{mg} \cdot \mathrm{L}^{-1}$} & $54.5 \pm 4.8$ & $35.4 \pm 5.0$ & $49.9 \pm 4.7$ & $70.6 \pm 7.1$ \\
\hline & \multicolumn{4}{|c|}{ Berry size ( $g / 50$ berries) } \\
\hline Control & $55.4 \pm 3.6$ & $45.0 \pm 2.2$ & $47.9 \pm 1.9$ & $40.1 \pm 2.9$ \\
\hline \multirow[t]{2}{*}{$10 \mathrm{mg} \cdot \mathrm{L}^{-1}$} & $66.1 \pm 2.6$ & $54.4 \pm 1.7$ & $49.0 \pm 1.6$ & $39.4 \pm 2.6$ \\
\hline & \multicolumn{4}{|c|}{ Percent ripe berries on May 10} \\
\hline Control & $1 \%$ to $3 \%$ & $10 \%$ to $15 \%$ & $35 \%$ & $72 \%$ \\
\hline $10 \mathrm{mg} \cdot \mathrm{L}^{-1}$ & $<1 \%$ & $1 \%$ to $5 \%$ & $27 \%$ & $53 \%$ \\
\hline
\end{tabular}

${ }^{\mathrm{z}}$ Controls were not treated.

${ }^{y}$ Values are means \pm SE with $\mathrm{n}=12$.

Table 4. Fruit set and berry weight of three southern highbush blueberry cultivars in response to CPPU applications under field conditions. ${ }^{2}$

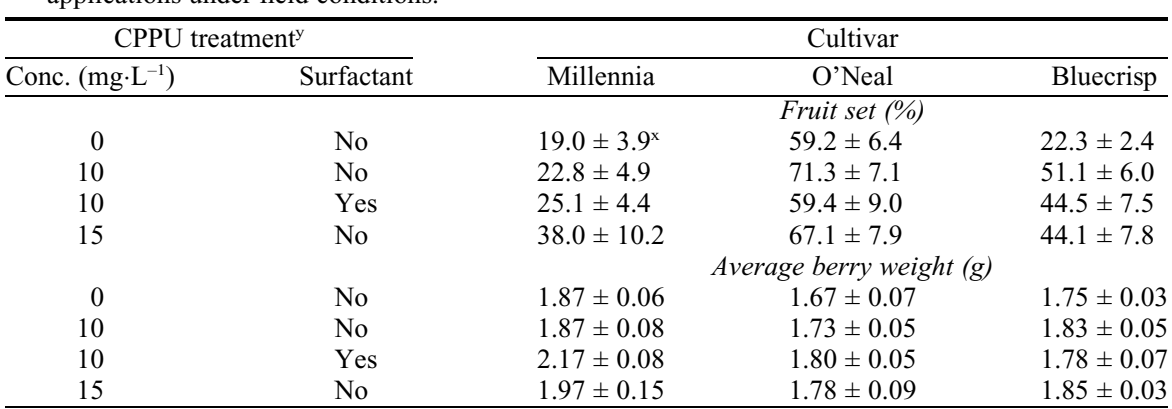

${ }^{\mathrm{z}}$ Data were taken at a grower site in Ware County, GA, during 2005.

${ }^{y}$ CPPU sprays were applied $10 \mathrm{~d}$ after full bloom (DAFB) for Millennia and 13 DAFB for O'Neal and Bluecrisp.

${ }^{\mathrm{x}}$ Values are means $\pm \mathrm{SE}$

Table 5. Effect of CPPU on berry yield and mean fresh weight of three southern highbush cultivars in 2001.

\begin{tabular}{lccccccc}
\hline & \multicolumn{3}{c}{ Yield (g/plant) } & & \multicolumn{3}{c}{ Berry size (g/berry) } \\
\cline { 2 - 4 } \cline { 6 - 8 } CPPU treatment & Sharpblue & Star & Santa Fe & & Sharpblue & Star & Santa Fe \\
\hline Control $^{z}$ & $2750 \mathrm{a}^{y}$ & $3656 \mathrm{~d}$ & $2066 \mathrm{a}$ & & $1.21 \mathrm{~b}$ & $1.04 \mathrm{~b}$ & $1.18 \mathrm{c}$ \\
$5 \mathrm{mg} \cdot \mathrm{L}^{-1}$ at $14 \mathrm{DAFB}$ & $2479 \mathrm{ab}$ & $5259 \mathrm{a}$ & $2013 \mathrm{a}$ & & $1.46 \mathrm{a}$ & $1.57 \mathrm{a}$ & $1.48 \mathrm{ab}$ \\
$5 \mathrm{mg} \cdot \mathrm{L}^{-1}$ at $10 \mathrm{DAFB}+$ & $1873 \mathrm{ab}$ & $4911 \mathrm{ab}$ & $1282 \mathrm{a}$ & & $1.34 \mathrm{ab}$ & $1.53 \mathrm{a}$ & $1.36 \mathrm{~b}$ \\
$5 \mathrm{mg} \cdot \mathrm{L}^{-1}$ at $20 \mathrm{DAFB}$ & & & & & & & \\
$10 \mathrm{mg} \cdot \mathrm{L}^{-1}$ at $14 \mathrm{DAFB}$ & $1895 \mathrm{ab}$ & $4089 \mathrm{~cd}$ & $1848 \mathrm{a}$ & & $1.47 \mathrm{a}$ & $1.46 \mathrm{a}$ & $1.47 \mathrm{ab}$ \\
$10 \mathrm{mg} \cdot \mathrm{L}^{-1}$ at $10 \mathrm{DAFB}+$ & & & & & & \\
$10 \mathrm{mg} \cdot \mathrm{L}^{-1}$ at $20 \mathrm{DAFB}$ & $1520 \mathrm{~b}$ & $4443 \mathrm{bc}$ & $2007 \mathrm{a}$ & & $1.51 \mathrm{a}$ & $1.59 \mathrm{a}$ & $1.50 \mathrm{a}$ \\
\hline
\end{tabular}

${ }^{2}$ Controls were sprayed with water and surfactant at 14 DAFB.

${ }^{y}$ Means followed by the same letter, within columns, are not significantly different, Duncan's multiple range test, $P \leq 0.05$.

${ }^{x} \mathrm{DAFB}=$ days after full bloom. 


\begin{tabular}{|c|c|c|c|c|c|c|}
\hline \multirow[b]{3}{*}{ CPPU treatment } & \multicolumn{3}{|c|}{ Star } & \multicolumn{3}{|c|}{ Millennia } \\
\hline & \multirow{2}{*}{$\begin{array}{c}\text { Berry size } \\
\text { (g/berry) }\end{array}$} & \multicolumn{2}{|c|}{ Cumulative yield ( $\%$ of total) } & \multirow{2}{*}{$\begin{array}{c}\text { Berry size } \\
\text { (g/berry) }\end{array}$} & \multicolumn{2}{|c|}{ Cumulative yield ( $\%$ of total) } \\
\hline & & $4 / 24-5 / 6$ & $4 / 24-5 / 15$ & & $4 / 15-4 / 29$ & $4 / 15-5 / 13$ \\
\hline Control $^{\mathrm{z}}$ & $1.22 \mathrm{c}^{\mathrm{y}}$ & $52.4 \mathrm{a}$ & $94.4 \mathrm{a}$ & $1.43 \mathrm{~b}$ & $28.3 \mathrm{a}$ & $78.9 \mathrm{a}$ \\
\hline $10 \mathrm{mg} \cdot \mathrm{L}^{-1}$ at full bloom & $1.41 \mathrm{ab}$ & $40.2 \mathrm{~b}$ & $90.4 \mathrm{ab}$ & $1.56 \mathrm{ab}$ & $26.8 \mathrm{a}$ & $75.4 \mathrm{a}$ \\
\hline $10 \mathrm{mg} \cdot \mathrm{L}^{-1}$ at $7 \mathrm{DAFB}^{\mathrm{x}}$ & $1.34 \mathrm{bc}$ & $43.3 \mathrm{ab}$ & $89.4 \mathrm{~b}$ & $1.40 \mathrm{~b}$ & $20.0 \mathrm{a}$ & $72.1 \mathrm{a}$ \\
\hline $10 \mathrm{mg} \cdot \mathrm{L}^{-1}$ at $14 \mathrm{DAFB}$ (Star) or 20 DAFB (Mill.) & $1.44 \mathrm{ab}$ & $28.4 \mathrm{c}$ & $78.9 \mathrm{c}$ & $1.60 \mathrm{a}$ & $24.6 \mathrm{a}$ & $77.2 \mathrm{a}$ \\
\hline $\begin{array}{l}5 \mathrm{mg} \cdot \mathrm{L}^{-1} \text { at full bloom }+5 \mathrm{mg} \cdot \mathrm{L}^{-1} 7 \mathrm{DAFB} \\
5 \mathrm{mg} \cdot \mathrm{L}^{-1} \text { at } 7 \mathrm{DAFB}+5 \mathrm{mg} \cdot \mathrm{Lv} \text { at } 14 \mathrm{DAFB} \text { (Star) }\end{array}$ & $1.36 \mathrm{~b}$ & $45.7 \mathrm{ab}$ & $90.1 \mathrm{ab}$ & $1.41 \mathrm{~b}$ & $27.2 \mathrm{a}$ & $78.6 \mathrm{a}$ \\
\hline or 20 DAFB (Mill.) & $1.53 \mathrm{a}$ & $27.4 \mathrm{c}$ & $83.1 \mathrm{c}$ & $1.51 \mathrm{ab}$ & $25.8 \mathrm{a}$ & $76.9 \mathrm{a}$ \\
\hline
\end{tabular}

${ }^{\mathrm{z} C o n t r o l s ~ w e r e ~ n o t ~ t r e a t e d . ~}$

${ }^{\mathrm{y}}$ Means followed by the same letter, within columns, are not different, Duncan's multiple range test, $P \leq 0.05$.

${ }^{x} \mathrm{DAFB}=$ days after full bloom

some of the other CPPU treatments. Conversely, 'Star', which showed the least amount of spray injury, had increased yields from most of the CPPU treatments. In 2002, fruit yields were unaffected by any of the CPPU treatments when compared with the controls (data not shown).

In 2001, seasonal mean berry fresh weights of 'Star' and 'Santa Fe' were increased by all CPPU treatments (Table 5). Mean berry weight of 'Sharpblue' was increased by all CPPU treatments except for the split application of $5 \mathrm{mg} \cdot \mathrm{L}^{-1}$ of CPPU applied 10 DAFB and again 20 DAFB. In 2002, all CPPU treatments except for $10 \mathrm{mg} \cdot \mathrm{L}^{-1}$ applied at 7 DAFB increased the mean berry weight of 'Star' when compared with control fruit (Table 6). 'Millennia' was less responsive than 'Star'. However, $10 \mathrm{mg}$. $\mathrm{L}^{-1}$ CPPU applied at 20 DAFB increased 'Millennia' seasonal mean berry weight compared with control fruit (Table 6).

In 2001, there was a trend toward delayed fruit ripening for most of the CPPU treatments (data not shown). The delay was most noticeable when young emerging leaves were burned by spray applications. In 2002, several CPPU treatments resulted in delayed fruit ripening of 'Star' but not 'Millennia', although no spray burn was noted that year (Table 6). The greatest delay in fruit ripening appeared to be associated with the treatments that increased mean berry weight the most.

In 2001, considerable spray burn was associated with most of the CPPU treatments. 'Sharpblue' was affected more than the other cultivars, which probably accounted for the reduced yield of 'Sharpblue' at the $10 \mathrm{ppm}$ split application in 2001. In 2002, no spray burn was observed for any of the CPPU treatments. Two notable differences between the 2001 and 2002 studies were: 1) sprays were applied to drip in 2001 and to complete coverage in 2002 . Therefore, spray volumes were greater in 2001 than in 2002; and 2) a surfactant was included in the 2001 sprays but not in the 2002 sprays. It appears likely that the higher spray volumes used in 2001, or the addition of a surfactant in 2001, contributed to the spray burn observed in 2001 but not in 2002.

Overall, the data from these greenhouse and field experiments indicate that CPPU can increase fruit set and berry size of southern highbush blueberries. Consequently, total fruit yield may also be increased by CPPU. However, these responses appear to be cultivar-dependent and varied with year, rate, and timing of sprays relative to bloom. Fruit set was increased in both greenhouse and field experiments in Georgia, but not in field experiments in Florida where natural fruit set was high and probably approaching the maximum carrying capacity of the plants. The effect of CPPU on fruit set may be heavily influenced by the presence or absence of other factors leading to high natural fruit set. CPPU sprays delayed fruit maturity in several of the experiments. This result is not surprising because maturity date of southern highbush blueberry is often related to crop load. Several CPPU treatments resulted in burn or necrosis of newly emerging leaves, which could be detrimental to yields and probably contributed to delayed fruit maturity in some cases. This was observed under both greenhouse and field conditions and in multiple years. The addition of a surfactant appeared to increase the occurrence of spray injury, but other factors such as cultivar sensitivity, growth stage, and spray volume may also be involved. CPPU should be further explored for use in southern highbush blueberry production. Additional research examining yields, berry quality, and time of harvest is needed to determine possible benefits of the growth regulator. Also, the issue of CPPU causing leaf burn needs careful examination.

\section{Literature Cited}

Antognozzi, E., F. Famiani, A. Palliotti, and A. Tombesi. 1993a. Effects of CPPU (cytokinin) on kiwifruit productivity. Acta Hort. 329:150-152.

Antognozzi, E., P. Proietti, and M. Boco. 1993b. Effect of CPPU (cytokinin) on table olive cultivars. Acta Hort. 329:153-155.

Greene, D.W. 1989. CPPU influences 'McIntosh' apple crop load and fruit characteristics. HortScience 24:94-96.

Greene, D.W. 1993. A comparison of the effects of several cytokinins on apple fruit set and fruit quality. Acta Hort. 329:144-146.

Looney, N.E. 1993. Improving fruit size, appearance, and other aspects of fruit crop 'quality' with plant bioregulating chemicals. Acta Hort. 329:120-127.

NeSmith, D.S. 2002. Response of rabbiteye blueberry (Vaccinium ashei Reade) to the growth regulators CPPU and gibberellic acid. HortScience 37:666-668.

NeSmith, D.S. 2005. Use of plant growth regulators in blueberry production in the southeastern U.S. Int. J. Fruit Sci. 5:41-52.

NeSmith, D.S. and H.M. Adair. 2004. Rabbiteye blueberry field trials with the growth regulator CPPU. Small Fruit Rev. 3:183-191.

Reynolds, A.G., D.A. Wardle, C. Zurowski, and N.E. Looney. 1992. Phenylureas CPPU and thidiazuron affect yield components, fruit composition, and storage potential of four seedless grape selections. J. Amer. Soc. Hort. Sci. 117: 85-89.

Sugiyama, N. and Y.T. Yamaki. 1995. Effects of CPPU on fruit set and fruit growth in Japanese persimmon. Sci. Hort. 60:337-343. 